VOLUME 2 EDISI 2, DESEMBER 2017

P-ISSN: 2527-9313, E-ISSN: 2548-9747

This work is licensed under a Creative Commons Attribution-NonCommercial4.0 International License

Review Buku:

Menyingkap Tabir Kuasa di Tanah Buton: Orang Kalisusu, Identitas, dan Kekuasaan. Nurlin, Ombak, Yogyakarta, 2017, 282 halaman. Daftar Pustaka. Index. ISBN 978-602-258-430-8

\title{
Kuasa: Perkawinan Masa Lalu dan Masa Kini
}

\section{Yusran Darmawan}

Pusat Studi Pembangunan Pertanian dan Pedesaan (PSP3) Institut Pertanian Bogor (IPB).

Email: timur_angin@yahoo.com

Buku yang berjudul Menyingkap Tabir Kuasa di Tanah Buton yang ditulis Nurlin ini adalah sumbangan berharga bagi studi-studi tentang Buton. Sejauh ini, studi tentang Buton hanya fokus pada apa yang terjadi di jantung kekuasaan tradisional Buton, yakni di Wolio, diantaranya Zuhdi (1999), Rudyansjah (2009), dan Tahara (2015). Namun, Nurlin menyajikan narasi tentang Kulisusu, satu daerah dalam lingkup Buton yang selama ini cenderung terabaikan dalam peta kajian.

Buku yang diangkat dari tesis Pascasarjana Antropologi ini hendak menjawab beberapa pertanyaan yang kerap kali muncul saat membahas pemekaran Kabupaten Buton Utara, diantaranya adalah mengapa memilih nama Buton Utara, bukan nama Muna Timur yang notabene menjadi induk wilayah ini. Bagi Nurlin, pemilihan nama itu memiliki argumentasi yang dipengaruhi oleh sejarah dan identitas. Ia lalu menelusuri perjalanan sejarah pemekaran, identitas masyarakat Kulisusu, hingga permainan kuasa di kalangan aktor pemekaran. Pesan yang hendak disampaikan adalah orang Kulisusu mengonstruksi identitas yang dalam posisi sejajar dengan orang Muna. Orang Kulisusu lalu menggunakan narasi sejarah sebagai bagian dari Kesultanan Buton demi menguatkan posisi mereka.

Secara umum buku ini bertujuan untuk membahas tiga permasalahan pokok, yakni: narasi historis tentang relasi kekuasaan yang berlangsung antara Kesultanan Buton dan Kulisusu, strategi kekuasaan yang diterapkan Kesultanan Buton untuk mempertahankan kekuasaannya di Kalisusu, dan 
reproduksi identitas dan kekuasaan orang Kulisusu yang mengacu pada wacana historisitas wilayah ini.

Buku ini membentangkan sejarah dan melihat bagaimana jejaknya di masa kini, mengawinkan antara riset Antropologi dan Sejarah sebagai dua sisi koin yang saling melengkapi. Tema-tema sejarah memang sudah lama menjadi perhatian para antropolog, sebagaimana dinyatakan oleh Comaroff (1992), bahwa tak ada satupun etnografi yang sanggup menyelami realitas permukaan kehidupan sehari-hari (the everyday life) atau menceburkan diri dalam bentuk-bentuk yang tak tampak (invisible), tanpa dilengkapi imajinasi sejarah. Imajinasi adalah sesuatu yang sentral dalam sejarah dan menjadi kepak sayap yang melambungkan ilmu sejarah ke langit pengetahuan.

Istilah etnografi sejarah adalah peristilahan yang baru muncul, namun telah lama dilakukan oleh para antropolog. Sahlins (1985) pernah menganalisis sejarah suku Maori ketika menyusun etnografi ketua suku demi memahami sejarah Maori. Etnografi bisa menjelaskan banyak hal, termasuk pengalaman subyek serta pengalaman kesejarahan subyek sebagai manusia yang hidup di muka bumi. Clifford Geertz (1986) juga menggunakan data sejarah untuk memahami realitas sosial dalam studinya di Mojokuto.

Aspek sejarah yang didiskusikan dalam buku ini adalah dinamika antara Kesultanan Buton dan daerah-daerah di bawahnya, serta bagaimana jejaknya di masa kini. Di kalangan orang Wolio, terdapat anggapan bahwa Kesultanan Buton serupa perahu yang ditopang empat cadik (Kaledupa, Muna, Tiworo, dan Kulisusu), dan disebut barata. Keempat barata ini memiliki otonomi pemerintahan, namun pada titik tertentu orang Wolio tetap memaksakan dominasinya melalui penguasa dan mitos-mitos yang dilestarikan. Di masingmasing wilayah, seringkali terdapat resistensi dan dinamika dengan pusat kekuasaan.

Buku ini juga mendialogkan beberapa teori mengenai kekuasaan, khususnya teori-teori dari Foucault dan Bourdieu, dengan beberapa kenyataan lapangan. Teori-teori tersebut dipadukan dengan kedalaman etnografis yang kaya mengenai dinamika antara Buton dan Kulisusu. Nurlin mengangkat kepingkeping realitas dari bawah, dari perspektif orang Kulisusu sendiri. Perspektif ini terasa menyegarkan karena Buton dilihat dari tepian, dari satu daerah paling ujung, yang selama ini tidak banyak dibahas oleh para peneliti.

Buku ini bukan tanpa cacat, terutama karena tidak dilengkapi dengan data-data sejarah yang terkait dengan terbentuknya Sulawesi Tenggara. Peristiwa ini menjadi mata rantai penting untuk menjelaskan bagaimana identitas Kulisusu 
pernah berada pada titik nadir, setelah itu bangkit kembali saat pemekaran Buton Utara. Penulis lebih banyak mengutip riset Hadara (2010), padahal jika melengkapinya dengan riset pustaka yang mendalam di gedung arsip, riset ini akan jauh lebih 'berwarna'.

Selain itu, penulis buku harus berhati-hati dan tidak terjebak pada apa yang diistilahkan oleh Amri Marzali (1999) sebagai 'romantisme antropologika' saat melakukan riset. Ini penting untuk digarisbawahi mengingat penulis adalah bagian dari masyarakat Kulisusu sendiri. Menurut Marzali, seorang peneliti sering terjebak dalam rimba raya perasaannya ketika melakukan riset. Ia terbelit oleh sulur-sulur perasananya sendiri saat mendefinisikan satu kenyataan sosial. Marzali menjelaskan sikap romantik yang menggebu-gebu pada seorang peneliti, sehingga secara membabi-buta membela satu masyarakat, tanpa menelusuri kenyataan itu lebih jauh dan mendalam.

Tak berlebihan jika saya mengatakan buku ini adalah persembahan berharga bagi masyarakat Kulisusu. Kerja seorang antropolog tak sekadar menyatakan 'I've been there', tapi juga memberikan persembahan etnografi sebagai jendela untuk memahami lukisan pengalaman satu masyarakat. 